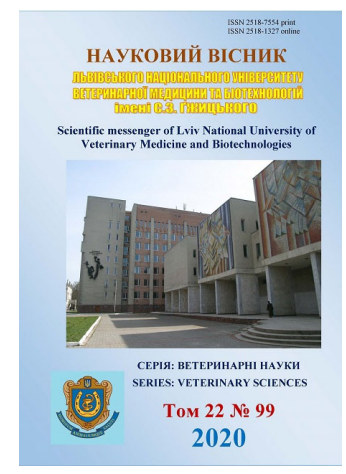

Науковий вісник Дьвівського національного університету ветеринарної медицини та біотехнодогій імені С.3. Гжицького. Серія: Ветеринарні науки

\author{
Scientific Messenger of Lviv National University \\ of Veterinary Medicine and Biotechnologies. \\ Series: Veterinary sciences
}

\title{
Influence of protein-mineral feed additive from marine aquatic organisms on growth intensity and nonspecific resistance of broiler chickens under different microclimate conditions
}

\author{
N. I. Dankevych ${ }^{1}$, V. Z. Salata ${ }^{2}$ \\ ${ }^{1}$ Odessa State Agrarian University, Odesa, Ukraine \\ ${ }^{2}$ Stepan Gzhytskyi National University of Veterinary Medicine and Biotechnologies Lviv, Ukraine
}

Article info

Received 14.09.2020

Received in revised form 13.10.2020

Accepted 14.10.2020

Odessa State Agrarian University Panteleymonyvska Str., 13, Odessa, 65012, Ukraine.

Tel.: (048) 785-10-43

E-mail:dankevych82@gmail.com

Stepan Gzhytskyi National University of Veterinary Medicine and Biotechnologies Lviv, Pekarska Str., 50, Lviv, 79010 Ukraine.

Tel.: +38-067-728-89-33 E-mail:salatavolod@ukr.net
Dankevych, N. I., \& Salata, V. Z. (2020). Influence of protein-mineral feed additive from marine aquatic organisms on growth intensity and nonspecific resistance of broiler chickens under different microclimate conditions. Scientific Messenger of Lviv National University of Veterinary Medicine and Biotechnologies. Series: Veterinary sciences, 22(99), 155-160. doi: $10.32718 /$ nvlvet 9923

The conducted research was aimed at determination of the impact produced by feeding protein and mineral feed additive produced out of the primary processing aquatic organisms wastes: sea mussels, red algae as well as of the sea water upon the productivity and non-specific resistance of broiler chickens raised in conditions of the normative and non-normative characteristics of the broiler house microclimate. The feed additive was applied to 20-42 day broiler chickens of "Ross 308" cross. The studied broilers were clinically healthy. Throughout the entire experiment, a series of the sanitary and hygienic microclimate parameters were determined, such as temperature, humidity, rate of changes as well as bacterial contamination of air, content of ammonia and carbon dioxide in air, and illumination of the broiler house. The house temperature was measured every day with the aid of a common spirit-in glass thermometer. Air humidity was established with the aid of an August psychrometer, air draft speed, harmful gas concentrations and illumination indicators were measured in compliance with the generally accepted methods. Bacterial contamination was determined with the use of the method of microorganism precipitation on a solid breeding ground placed in Petri dishes followed by a count of the bacterial colonies per $1 \mathrm{~m}^{3}$. The blood analysis included determination of haemoglobin, erythrocytes and leukocytes. In the blood serum, the lysozyme activity (LABS) and bactericidal activity (BABS) were determined. It was established that enriching the basic ration with the protein and mineral additive in quantity of $7 \%$ in addition to the feed mass under conditions of the normative microclimate produced a positive effect on the growth intensity, livability and non-specific resistance indices of the broiler chickens. Thus, the live weight of broilers was reliably greater by $4.7 \%$ and the livability equalled $100 \%$. The haemoglobin content was reliably greater by $7.6 \%$, erythrocytes - by $11.5 \%, B A B S$ - by $34.5 \%$ and LABS - by $35.9 \%$ as compared with the control group of broiler chickens. At the same time, when the studied feed additive was fed to broiler chickens kept in the microclimate conditions that did not meet the normative requirements, the reliable difference to the control indices was not established. Hence, the research results have proved that application of the protein and mineral feed additive is effective under the optimal microclimate conditions. High figures of livability and growth intensity of broiler chickens are based on a high resistance which is being formed provided the optimal microclimate and application of feed additives have been provided.

Key words: broiler chickens, aquatic organisms, mussels, red algae, haemoglobin, erythrocytes, bactericidal lysozyme activity, microclimate parameters.

\section{Вплив білково-мінеральної кормової добавки 3 морських гідробіонтів на інтенсивність росту і неспецифічну резистентність курчат-бройлерів за рі- зних умов мікроклімату}




\section{Н. І. Данкевич ${ }^{1}$, В. 3. Салата ${ }^{2}$}

${ }^{1}$ Одеський державний аграрний університет, м. Одеса, Украӥна

${ }^{3}$ Львівський національний університет ветеринарної медицини та біотехнологій імені С. 3. Гюицького, м. Львів, Украӥна

Метою досліджень було встановити вплив згодовування білково-мінеральної кормової добавки, виготовленої з відходів первинної переробки гідробіонтів: морських мідій, червоних морських водоростей, а також морської води на стан продуктивності $і$ неспецифічної резистентності курчат-бройлерів в умовах нормативних і ненормативних параметрів мікроклімату пташників. Застосування кормової добавки проводили на курчатах-бройлерах кросу “Росс 308” 20-42-добового віку. Під час досліду птиия була клінічно здоровою. Упродовж усього експерименту визначали низку санітарно-гігієнічних параметрів мікроклімату: температуру, вологість і швидкість руху, а також бактеріальне забруднення повітря, вміст у ньому аміаку $і$ вуглекислого газу, а також освітленість приміщення. Вимірювання температури приміщення проводили щоденно за допомогою побутового спиртового термометра. Вологість повітря встановлювали за допомоги психрометра Августа, показники швидкості руху повітря, концентрацію шкідливих газів, показники освітленості - за загальноприйнятими методиками. Бактеріальне забруднення повітря визначали методом осадження мікроорганізмів на тверде поживне середовище у чашках Петрі з наступним підрахунком колоній бакте-

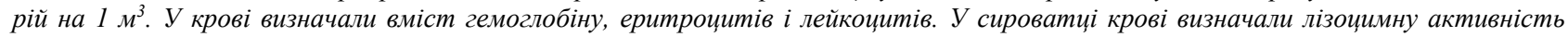
(ЛАСК), а також бактерицидну активність (БАСК). Встановлено, шо збагачення основного рачіону білково-мінеральною кормовою добавкою в кількості 7 \% додатково до маси корму в умовах нормативного мікроклімату позитивно вплинуло на інтенсивність росту, збереженість, а також показники неспецифічної резистентності курчат-бройлерів. Так, жива маса курчат була достовірно більшою на 4,7\%, збереженість становила $100 \%$ Порівняно з контролем були достовірно більиими: вміст гемоглобіну на 7,6 \%, еритрочитів - на 11,5\%, БАСК - на 34,5\%, ЛАСК - на 35,9\%. Натомість, за умови згодовування досліджуваної кормової добавки курчатам-бройлерам в умовах мікроклімату, ияо не відповідав нормативним вимогам, достовірної різниці з показниками контролю не встановлено. Отже, результати дослідження засвідчили, щяо використання білково-мінеральної кормової добавки є ефективним в умовах оптимального мікроклімату. Високі показники збереженості і інтенсивності росту курчатбройлерів забезпечуються високою резистентністю, що формується за умови забезпечення оптимального мікроклімату і використання кормових добавок.

Ключові слова: курчата, морські гідробіонти, еритроцити, гемоглобін, БАСК, ЛАСК, параметри мікроклімату.

\section{Вступ}

Продуктивність курей залежить від багатьох санітарно-гігієнічних та технологічних факторів: способу утримання, розміру груп, щільності посадки, параметрів мікроклімату, організації годівлі. За кожним санітарно-гігієнічним показником (температура, вологість, швидкість руху повітря і ступінь його забруднення, фронт годівлі і напування, світловий режим) встановлено певні діапазони їх значень, за яких птахи витрачають мінімальну кількість енергії для підтримки фізіологічних процесів на оптимальному рівні (Demchuk et al., 2006; Bogatko et al., 2017; Ventura \& da Silva, 2019). У той же час, використання кормових добавок може значно покращити кількісні і якісні показники їх продуктивності, забезпечити ефективне використання кормових ресурсів (Szabó et al., 2005; Beski et al., 2015; Kukhtyn et al., 2020).

Можливим джерелом збагачення раціонів сільськогосподарських тварин поживними і біологічно активними речовинами $є$ морські гідробіонти. Одними 3 них можуть бути морські мідії і червоні водорості (Ikusika et al., 2019). До складу стулок мідій входять Кальцій, Фосфор, інші макро- і мікроелементи, що необхідні організму тварин і добре засвоюються. Тіла мідій містять значну кількість повноцінного протеїну (Morris et al., 2019). Враховуючи, що м'ясо мідій є цінним продуктом для людини, в годівлі тварин його не застосовують. Для виготовлення кормових добавок можна використовувати відходи їх первинної переробки: стулки великих і тіла дрібних мідій (Jonsson \& Elwinger, 2009). Червоні морські водорості є багатим джерелом поживних і біологічно активних речовин, найбільш “врожайними” рослинами моря. За вмістом поживних речовин їх прирівнюють до якісного зерна. У значній кількості такі водорості містять протеїн, жир, клітковину, безазотні екстрактивні мінеральні речовини, а також Йод (Gómez-Ordóñez et al., 2012; Souza et al., 2012; de Jesus Raposo et al., 2015).

Використання морських гідробіонтів в годівлі сільськогосподарської птиці є перспективним заходом 3 точки зору підвищення якості яєць, м'яса, ефективності використання корму (Świątkiewicz \& ArczewskaWlosek, 2012). Крім того, використання відходів первинної переробки морських гідробіонтів у годівлі сільськогосподарських тварин сприяло б вирішенню важливої екологічної і економічної проблеми - їх утилізації (McLaughlan et al., 2014).

Мeта роботи - встановити вплив білковомінеральної кормової добавки, виготовленої з морських гідробіонтів на стан продуктивності і неспецифічної резистентності курчат-бройлерів в умовах нормативних і ненормативних параметрів мікроклімату пташників.

\section{Матеріал і методи досліджень}

Експериментальні дослідження проводили на курчатах-бройлерах кросу "Росс 308" в ПП “АГРОФІРМА БУДАКИ” Одеської обл. Під час досліду птиця була клінічно здоровою. Утримання курчат та маніпуляції з ними виконували згідно положень документу “Загальні етичні принципи експериментів на тваринах”, ухваленого Першим Національним конгресом 3 біоетики (Київ, 2001 р.).

Перші 20 діб курчата знаходились в однакових умовах годівлі і утримання. На 21 добу було сформовано 3 групи птиці (контрольну і дві дослідні) по 
50 голів, яких утримували у клітках різних пташників за утримання на підлозі. Всього дослід тривав 42 доби. Упродовж нього курчата контрольної групи отримували тільки основний раціон, що був збалансованим за основними показниками (табл. 1).
Курчата-бройлери першої і другої дослідної групи отримували раціон, до якого додавали білковомінеральну кормову добавку (табл. 2).

\section{Таблиця 1}

Склад повнораціонного комбікорму для курчат-бройлерів віком 4-6 тижнів

\begin{tabular}{|c|c|c|}
\hline \multirow{2}{*}{ Показники } & \multicolumn{2}{|c|}{ Склад комбікорму } \\
\hline & $\%$ & $\Gamma$ \\
\hline Пшениця & 30 & 30 \\
\hline Ячмінь & 3 & 3 \\
\hline Кукурудза & 25 & 25 \\
\hline Макуха соняшникова & 10 & 10 \\
\hline Макуха соєва & 25 & 25 \\
\hline $\begin{array}{l}\text { Білково-вітамінна добавка для курчат-бройлерів віком 1-3 тижнів } \\
5 \text { \% “Годівля Нова” }\end{array}$ & 5 & 5 \\
\hline Соняшникова або соєва олія, фуз олійний & 2 & 2 \\
\hline Разом & 100 & 100 \\
\hline
\end{tabular}

\section{Таблиця 2}

Схема досліду

\begin{tabular}{|c|c|c|c|c|}
\hline \multirow{2}{*}{ Група } & \multicolumn{2}{|c|}{ Тривалість періоду, діб } & \multirow{2}{*}{$\begin{array}{c}\text { Кількість } \\
\text { курчат, гол. }\end{array}$} & \multirow{2}{*}{ Особливості годівлі } \\
\hline & зрівняльний & основний & & \\
\hline Контрольна & 8 & 22 & 50 & Основний раціон \\
\hline Дослідна 1 & 8 & 22 & 50 & $\begin{array}{c}\text { OP + білково-мінеральна добавка у кількості } 7 \text { г/100 г } \\
\text { комбікорму }\end{array}$ \\
\hline Дослідна 2 & 8 & 22 & 50 & $\begin{array}{c}\text { OP + білково-мінеральна добавка у кількості } 7 \text { г/100 г } \\
\text { комбікорму }\end{array}$ \\
\hline
\end{tabular}

Птицю утримували в клітках двох пташників. Птицю контрольної і першої дослідної групи утримували у пташнику, де підтримували показники мікроклімату, що відповідали нормативним параметрам згідно ВНТП-АПК-04.05. Птицю другої дослідної групи утримували в пташнику, де параметри мікроклімату не повністю відповідали цим параметрам.

Упродовж усього досліду визначали низку санітарно-гігієнічних параметрів мікроклімату: температуру, вологість і швидкість руху, а також бактеріальне забруднення повітря, вміст у ньому аміаку і вуглекислого газу, а також освітленість приміщення. Вимірювання температури приміщення проводили щоденно за допомогою побутового спиртового термометра. Вологість повітря визначали психрометром Августа, показники швидкості руху повітря, концентрацію шкідливих газів, показники освітленості - за загальноприйнятими методиками (Demchuk et al., 2006). Бактеріальне забруднення повітря визначали методом осадження мікроорганізмів на тверде поживне середовище у чашках Петрі 3 наступним підрахунком колоній бактерій та перерахунком на $1 \mathrm{~m}^{3}$ повітря.

Білково-мінеральну кормову добавку використовували в формі пасти, що була виготовлена 3 дрібно мелених відходів первинної переробки морських гідробіонтів: стулок великих і тіл дрібних чорноморських мідій (Mytilus galloprovincialis), морської червоної водорості філофори ребристої (Phyllophora nervosa) “йодки”, а також морської води (Kovbasenko \& Dronova, 2008; Kovbasenko \& Karajvan, 2009).
У крові визначали кількість гемоглобіну, еритроцитів і лейкоцитів. У сироватці крові визначали лізоцимну активність (ЛАСК) нефелометричним методом за Дорофейчуком В. Г. (1968), а також бактерицидну активність (БАСК) фотонефелометричним кюветним методом за Ю.М. Марковим (Vlizlo et al., 2012).

\section{Результати та їх обговорення}

Гігієнічні показники (щільність посадки, світловий режим, газовий склад повітря) у пташнику, де утримували курчат контрольної і першої дослідної групи, відповідав параметрам ВНТП-АПК-03-05. (птахівничі підприємництва). Щільність посадки становила 7 гол. курчат на $1 \mathrm{M}^{2}$ підлоги, освітленість - лк/м².

За результатами визначення санітарно-гігієнічного стану мікроклімату в приміщенні для курчатбройлерів контрольної і першої дослідної групи, яке виконували впродовж кожного дня останнього тижня досліду, встановлено такі його показники (табл. 3): температура повітря - 24,4 $\pm 0,21{ }^{\circ} \mathrm{C}$, його відносна вологість - $57,3 \pm 0,78 \%$, швидкість руху $0,35 \pm 0,04 \mathrm{~m} / \mathrm{c}$, вміст у ньому аміаку $18,5 \pm 0,04 \mathrm{Mг} / \mathrm{M}^{3}, \quad$ вміст вуглекислого газу $2,4 \pm 0,01$ л $/ \mathrm{M}^{3}$, бактеріальне забруднення повітря $178,61 \pm 5,87$ тис. КУО/М³ ${ }^{3}$ У клітці курчат другої дослідної групи показники мікроклімату відрізнялись від таких контрольної і першої дослідної групи і становили: температура повітря - 27,6 $\pm 0,23{ }^{\circ} \mathrm{C}$, його відносна вологість - 68,4 $\pm 2,51 \%$, його швидкість 
руху $-0,28 \pm 0,03 \mathrm{м} / \mathrm{c}$, уміст аміаку $-26,4 \pm 0,05 \mathrm{мг} / \mathrm{M}^{3}$, уміст вуглекислого газу $-2,8 \pm 0,01$ л/м $\mathrm{m}^{3}$, бактеріальне забруднення повітря $-258,43 \pm 6,87$ тис. КУО/М²

Отже, параметри мікроклімату в приміщенні, де утримували курчат другої дослідної групи, не в пов- ній мірі відповідав нормативам, рекомендованих ВНТП-АПК-04.05.

За результатами забою курчат-бройлерів, який було проведено в кінці досліду, було встановлено такі їх показники (табл. 4).

Таблиця 3

Параметри мікроклімату в приміщеннях для курчат-бройлерів, $\mathrm{M} \pm \mathrm{m}, \mathrm{n}=7$

\begin{tabular}{|c|c|c|c|c|}
\hline \multirow{2}{*}{ Показники, що досліджували } & \multicolumn{3}{|c|}{ Група } & \multirow{2}{*}{ Нормативи } \\
\hline & контрольна & дослідна 1 & дослідна 2 & \\
\hline Температура повітря, ${ }^{\circ} \mathrm{C}$ & \multicolumn{2}{|c|}{$24,4 \pm 0,21$} & $27,6 \pm 0,23$ & 20 \\
\hline Відносна вологість повітря, \% & \multicolumn{2}{|c|}{$57,3 \pm 0,78$} & $68,4 \pm 2,51$ & $65-70$ \\
\hline Швидкість руху повітря, м/с & \multicolumn{2}{|c|}{$0,35 \pm 0,04$} & $0,28 \pm 0,03$ & $0,1-0,5$ \\
\hline Концентрація (аміак) $\mathrm{NH}_{3}$, мг/м ${ }^{3}$ & \multicolumn{2}{|c|}{$18,5 \pm 0,04$} & $26,4 \pm 0,05$ & 15,0 \\
\hline Концентрація (вуглекислота) $\mathrm{CO}_{2}$, л/м ${ }^{3}$ & \multicolumn{2}{|c|}{$2,4 \pm 0,01$} & $2,8 \pm 0,01$ & 0,25 \\
\hline Бактеріальне забруднення повітря, тис. КУО/м³ & \multicolumn{2}{|c|}{$178,61 \pm 5,87$} & $258,43 \pm 6,87$ & 50 \\
\hline
\end{tabular}

\section{Таблиця 4}

Показники живої маси і витрат корму для курчат-бройлерів за різних умов утримання і згодовування кормової добавки, $\mathrm{M} \pm \mathrm{m}, \mathrm{n}=50$

\begin{tabular}{|c|c|c|c|}
\hline \multirow{2}{*}{ Показники } & \multicolumn{3}{|c|}{ Група } \\
\hline & Контрольна & Дослідна 1 & Дослідна 2 \\
\hline \multicolumn{4}{|l|}{ Голів у групі: } \\
\hline - на початок досліду & 50 & 50 & 50 \\
\hline - $\quad$ в кінці досліду & 50 & 50 & 46 \\
\hline \multicolumn{4}{|l|}{ Маса тіла курчат, г: } \\
\hline - на початок досліду & 42,05 & 42,03 & 41,93 \\
\hline Жива маса у віці 20 діб, г & $830,2 \pm 24,3$ & $828,0 \pm 20,80$ & $832,7 \pm 22,7$ \\
\hline Жива маса у віці 42 доби, г & $2617,1 \pm 28,38$ & $2740,3 \pm 25,82 * *$ & $2636,0 \pm 19,54$ \\
\hline Приріст живої маси на групу, кг & 89,35 & 95,62 & 82,95 \\
\hline Середньодобовий приріст, г & 61,3 & 64,2 & 61,6 \\
\hline Збереженість, \% & 100,0 & 100,0 & 96,0 \\
\hline Спожито корму за 22 доби, г/гол. & 3396 & 3393 & 3397 \\
\hline Витрати корму на групу, кг & 169,8 & 169,65 & 169,85 \\
\hline Спожито БМД за 22 доби, г/гол. & & 237,95 & 237,95 \\
\hline Затрати корму за дослід, г/гол. & $9 \overline{30}, 0$ & 911,0 & 916,0 \\
\hline Затрати корму на 1 кг приросту, кг & 1,90 & 1,77 & 2,05 \\
\hline
\end{tabular}

Примітка: ** - $\mathrm{P} \leq 0,01$ порівняно до контролю

За результатами досліду встановлено, що збереженість курчат контрольної і першої дослідної групи становила $100 \%$, другої дослідної групи - 96,0\%. Жива маса курчат першої дослідної групи порівняно 3 контролем була більшою на $4,7 \%(\mathrm{P} \leq 0,01)$, другої дослідної групи - на 0,7 \%. Відповідно, добовий приріст був більшим у курчат першої дослідної групи на 4,8 \%, другої - на 0,5 \%. Наші дані щодо збільшення показника збереженості і інтенсивності росту курчатбройлерів за використання білково-мінеральної кормової добавки, виготовленої з морських гідробіонтів підтверджують інформацію Oso et al. (2011), Xing et al. (2020) про збільшення збереженості і маси тіла курей, а також курчат-бройлерів за використання кормових добавок, виготовлених з морських молюсків. 3 іншого боку, отримані нами дані щодо відсутності стимулюючого впливу на інтенсивність росту курчат-бройлерів другої дослідної групи узгоджується 3 інформацією Buğdaycı et al. (2019) щодо відсутності збільшення маси тіла японських перепелів за використання стулок середземноморських мідій.
Відмінності в інтенсивності росту, споживанні корму і збереженості курчат дослідних і контрольної груп зумовили різницю в показниках затрат корму на 1 кг приросту живої маси. Якщо за період досліду у контрольної птиці витрати корму становили 1,90 кг на 1 кг приросту маси тіла, то в першій дослідній групі 1,77 кг, у другій дослідній групі - 2,05 кг, що було відповідно менше на 6,8 \% і більше на 7,9\%.

Як відомо, морфологічні показники крові курчат об'єктивно відображають їх адаптаційну здатність до гігієно-технологічних факторів, інтенсивність перебігу фізіологічних процесів, рівень обміну речовин. Кількість формених елементів крові є “дзеркалом" стану неспецифічної резистентності тварин (Bueno et al., 2017). Основні морфологічні показники крові курчат контрольної і дослідних груп, яким застосовували кормову добавку, яку виготовляли 3 відходів первинної переробки морських гідробіонтів, приведено в табл. 5. 


\section{Таблищя 5}

Морфологічні показники крові курчат дослідних груп, $\mathrm{M} \pm \mathrm{m}, \mathrm{n}=10$

\begin{tabular}{lrrr}
\hline \multicolumn{1}{c}{ Показники } & \multicolumn{3}{c}{ Група } \\
\cline { 2 - 4 } & контрольна & \multicolumn{1}{c}{ дослідна 1 } & дослідна 2 \\
\hline Гемоглобін, Г/л & $86,08 \pm 1,83$ & $92,61 \pm 1,77 *$ & $85,90 \pm 1,60$ \\
Еритроцити, Т/л & $2,88 \pm 0,11$ & $3,21 \pm 0,17$ & $2,97 \pm 0,23$ \\
Лейкоцити, Г/л & $29,34 \pm 1,08$ & $31,88 \pm 1,62$ & $28,03 \pm 1,34$ \\
\hline
\end{tabular}

Примітка: * - $\mathrm{P} \leq 0,05$ порівняно до контролю

Згідно даним, наведеним в таблиці, використання кормової добавки $з$ морських гідробіонтів в умовах нормативного мікроклімату сприяло збільшенню деяких показників крові курчат-бройлерів на 42 добу експерименту. Так, рівень гемоглобіну був більший на 7,6 \% (P $\leq 0,01)$, еритроцитів - на 11,5\%. Одержані нами дані узгоджуються $з$ інформацією Hrabčáková et al. (2014) стосовно наявності позитивної кореляції в птахів між кількістю еритроцитів, гемоглобіну і лейкоцитів. За використання кормової добавки в умовах невідповідного нормативам мікроклімату такі зміни не були достовірними. Уміст лейкоцитів у крові курчат першої і другої дослідних груп порівняно з контрольною групою достовірної різниці не мав.

Гуморальним фактором захисту у підтримці неспецифічної резистентності організму належить важлива роль. БАСК, як інтегральний показник природної резистентності, що відображає імунний стан організму. Результати визначення БАСК і ЛАСК у курчат дослідних груп наведені в табл. 6.

\section{Таблиця 6}

Гуморальні фактори неспецифічної резистентності крові курчат-бройлерів 42-добового віку, $\mathrm{M} \pm \mathrm{m} ; \mathrm{n}=5$

\begin{tabular}{lccc}
\hline \multirow{2}{*}{ Показник } & \multicolumn{2}{c}{ Група } \\
\cline { 2 - 4 } & контрольна & дослідна 1 & дослідна 2 \\
\hline БАСК & $30,08 \pm 2,15$ & $40,46 \pm 2,08^{* *}$ & $32,47 \pm 0,94$ \\
ЛАСК & $29,60 \pm 2,51$ & $40,22 \pm 3,03^{*}$ & $30,20 \pm 1,46$ \\
\hline Примітка: ${ }^{*}-\mathrm{P} \leq 0,05 ; * *-\mathrm{P} \leq 0,01$ порівняно до контролю & &
\end{tabular}

При визначенні потенційних можливостей гуморального імунітету в порівняльному аспекті дослідили ЛАСК і БАСК курчат контрольної і двох дослідних груп. Експериментальні дані вказують на те, що при утриманні курчат за умов нормативного мікроклімату i використанні білково-мінеральної добавки у них збільшується БАСК. Так, на 42 добу зафіксували підвищення цього показника в курчат першої дослідної групи на 34,5 \% (P $\leq 0,01)$. Згодовування кормової добавки в умовах ненормативного мікроклімату порівняно $з$ контролем цей показник достовірно не змінило, він був більшим на 7,9 \% $(\mathrm{P}>0,05)$. Аналогічно до змін БАСК, в кінці терміну вирощування ЛАСК у курчат першої дослідної групи була на 35,9 \% більшою (P $\leq 0,05)$, ніж в контролі. У курчат-бройлерів другої дослідної групи цей показник був більшим тільки на 2,0\% (P > 0,05).

Таким чином, результати дослідження показали, що адаптаційно-захисні функції в організмі дослідних курчат-бройлерів, які забезпечують високу резистентність і продуктивність, формуються за умови забезпечення в пташниках оптимальних показників мікроклімату і використання кормових добавок. Використання кормових добавок в умовах ненормативного мікроклімату показники продуктивності курчат і неспецифічної резистентності не збільшило.

\section{Висновки}

1. Згодовування курчатам-бройлерам білковомінеральної кормової добавки, виготовленої 3 морських гідробіонтів в умовах нормативного мікроклімату позитивно вплинуло на організм, сприяло високій збереженості, яка в курчат контрольної і першої дослідної групи становила 100 \%, курчат другої дослідної групи - 96,0%, а також більшим приростам живої маси курчат першої дослідної групи на 4,7 \%, другої дослідної групи - на $0,7 \%$. Відповідно добовий приріст був більшим у курчат першої дослідної групи на 4,6 \%, другої дослідної групи - на 0,6 \%.

2. Згодовування білково-мінеральної кормової добавки в умовах нормативного мікроклімату стимулювало еритроцитопоез, про що свідчило збільшення вмісту гемоглобіну на 7,6 \%, еритроцитів - на $11,5 \%$.

3. При використанні білково-мінеральної добавки при утриманні курчат за умов нормативного мікроклімату у них збільшується БАСК на 34,5\% $(\mathrm{P} \leq 0,01)$, ЛАСК - на 35,9 \% (P $\leq 0,05)$.

\section{References}

Beski S. S. M., Swick R. A., \& Iji, P. A. (2015). Specialized protein products in broiler chicken nutrition: A review. Animal Nutrition, 1(2), 47-53. doi: 10.1016/j.aninu.2015.05.005.

Bogatko, N., Bogatko, L., Salata, V., Semaniuk, V., Serdioucov, J., \& Schyrevuch, G. (2017). Veterinarysanitary control of safety and quality of meat products. Scientific Messenger of LNU of Veterinary Medicine and Biotechnologies. Series: Veterinary Sciences, 19(73), 7-10. doi: 10.15421/nvlvet7302. 
Bueno, J. P. R., Nascimento, M. R. B. M., Martins, J. M. S., Marchini, C. F. P., Gotardo, L. R. M., Sousa, G. M. R., Mundim, A. V., Guimarães, E. C., \& Rinaldi, F. P. (2017). Effect of age and cyclical heat stress on the serum biochemical profile of broiler chickens Influência da idade e do estresse cíclico de calor no perfil bioquímico sérico em frangos de corte. Semina: Ciências Agrárias, Londrina, 38(3), 1383-1392. doi: $10.32819 / 2020.81009$.

Buğdaycı, K. E., Gümüş, H., Oğuz, M. N., Karakaş Oğuz, F., \& Gülle, İ. (2019). Effects of Mediterranean Mussel Shell (Mytilus galloprovincialis) on Performance and Egg Quality in Laying Quails. Acta Vet Eurasia, 45, 22-29. doi: 10.26650/actavet.2019.18010.

de Jesus Raposo, M. F., de Morais, A. M., \& de Morais, R. M. (2015). Marine polysaccharides from algae with potential biomedical applications. Marine Drugs, 13, 2967-3028. doi: 10.3390/md13052967.

Demchuk, M. V., Chorny`j, M. V., Zaxarenko, M. O., \& Vy`sokos, M. P. (2006). Gigiyena tvary`n: pidruchny'k. Xarkiv: Espada (in Ukrainian).

Gómez-Ordóñez, E., Jiménez-Escrig, A., \& Rupérez, P. (2012). Effect of the red seaweed Mastocarpus stellatus intake on lipid metabolism and antioxidant status in healthy Wistar rats. Food Chemistry. 135, 806-811. doi: 10.1016/j.foodchem.2012.04.138.

Hrabčáková, P., Voslářová, E., Bedáňová, I., Pištěková, V., Chloupek, J., \& Večerek, V. (2014). Haematological and biochemical parameters during the laying period in common pheasant hens housed in enhanced cages. ScientificWorldJournal, 2014, 364602. doi: 10.1155/2014/364602.

Ikusika, O. O., Mpendulo, C. T., Zindove, T. J., \& Okoh, A. I. (2019). Fossil shell flour in livestock production: A Review. Animals (Basel), 9(3), 70. doi: 10.3390/ani9030070.

Jonsson, L., \& Elwinger, K. (2009). Mussel meal as a replacement for fish meal in feeds for organic poultry - a pilot short term study. Acta Agriculturae Scandinavica - Section A. Animal Science, 59, 22-27. doi: 10.1080/09064700902730158.

Kovbasenko, V. M., \& Dronova, N. I. (2008). Sposib oderzhannya kormovoyi dobavky' z mors`ky`x gidrobiontiv dlya pty`ci: pat. 34634 Ukrayina. u4200808275; zayavl. 19.06.2008; opubl. 11.08.2008; Byul. 15, 4 (in Ukrainian).

Kovbasenko V. M., \& Karajvan N. I. (2009). Sposib oderzhannya kormovoyi dobavky` z mors`ky`x gidrobiontiv dlya pty`ci: pat. 42687 Ukrayina. u 4200903402; zayavl. 09.04.2009; opubl. 10.07.2009; Byul. 13, 4 (in Ukrainian).

Kukhtyn, M., Salata, V., Berhilevych, O., Malimon, Z., Tsvihun, A., Gutyj, B., \& Horiuk, Y. (2020). Evaluation of storage methods of beef by microbiological and chemical indicators. Potravinarstvo Slovak Journal of Food Sciences, 14, 602-611. doi: 10.5219/1381.
McLaughlan, C., Rose, P., David, C., \& Aldridge, D. C. (2014). Making the Best of a Pest: The potential for using invasive zebra mussel (Dreissena polymorpha) biomass as a supplement to commercial chicken feed. Environmental Management, 54, 1102-1109. doi: 10.1007/s00267-014-0335-6.

Morris, J. P., Backeljau, T., \& Chapelle, G. (2019). Shells from aquaculture: a valuable biomaterial, not a nuisance waste product. Reviews in Aquaculture, 11, 4257. doi: 10.1111/raq.12225.

Oso, A. O., Idowu, A. A., \& Niameh, O. T. (2011). Growth response, nutrient and mineral retention, bone mineralisation and walking ability of broiler chickens fed with dietary inclusion of various unconventional mineral sources. Journal of Animal Physiology and Animal Nutrition, 95(4), 461-467. doi: 10.1111/j.1439-0396.2010.01073.x.

Souza, B. W. S., Cerqueira, M. A., Bourbon, A. I., Pinheiro, A. C., Martins, J. T., Teixeira, J. A., Coimbra, M., \& Vicente A. (2012). Chemical characterization and antioxidant activity of sulfated polysaccharide from the red seaweed Gracilaria birdiae. Food Hydrocolloids, 27, 287-292. doi: 10.1016/j.foodhyd.2011.10.005.

Świątkiewicz, S., \& Arczewska-Wlosek, A. (2012). Bone quality characteristics and performance in broiler chickens fed diets supplemented with organic acids. Czech Journal of Animal Science, 57(4), 193-205. doi: 10.17221/6004-cjas.

Szabó, A., Mézes, M., Horn, P., Sütő, Z., Bázár, G. Y., \& Romvári, R. (2005). Developmental dynamics of some blood biochemical parameters in the growing turkey (Meleagris gallopavo). Acta Veterinaria Hungarica, 53(4), 397-409. doi: 10.1556/AVet.53.2005.4.1.

Ventura, M. V. A., \& da Silva, R. M. (2019). Bone problems caused by the deficiency of calcium and phosphorus in the feeding of broilers. Biomedical Journal of Scientific \& Technical Research, 16(4), 12223-12226. doi: 10.26717/BJSTR.2019.16.002886.

Vlizlo, V. V., Fedoruk, R. S., \& Raty`ch, I. B. (2012). Laboratorni metody' doslidzhennya u biologiyi, tvary`nny`cztvi ta vetery`narnij medy`cy`ni: dovidny`k. L`viv: Spolom (in Ukrainian).

Xing, R., Yang, H., Wang, X., Yu, H., Liu, S., \& Li, P. (2020). Effects of calcium source and calcium level on growth performance, immune organ indexes, serum components, intestinal microbiota, and intestinal morphology of broiler chickens. The Journal of Applied Poultry Research, 29(1), 106-120. doi: 10.3382/japr/pfz033. 